\title{
A Social History of Parastatal Employees in Southern Benin, 1989-1990: Contesting Decline and Unemployment During “Africa's Second Democratization"
}

\author{
Alexander Keese \\ Université de Genève
}

\begin{abstract}
The huge parastatal sectors in postcolonial African societies interested sociologists in the 1970s and 1980s, but have never found a historical discussion - and the experience of change towards the democratization (eventually) has not yet been interpreted by historians. This study attempts to bring both elements together for the case of Benin, a country particularly shaken by massive economic decline, lay-offs and unemployment in the second half of the 1980s. It relies on an unusual and spectacular source, a series of petitions sent by workers and workers' delegates to the presidential office of Mathieu Kérékou in 1989/90 (the presidential office partly added to these petitions whole dossiers of comments and correspondence with other authorities, i.e. ministerial directorates and the police). This analysis highlights how parastatal workers and their spokesmen tried to communicate about economic and social disaster with the authorities, how they protested and attempted to make claims about social norms and justice, and how they attacked "corruption". I would hold that the cases studied cannot stand for a model of experiences, but they nevertheless represent a number of elements of a social history of decline: as well as protests and arguments, and views on the practice of petitioning, the discussion will also highlight individual trajectories that nevertheless exemplify, in my view, representative experiences and a history of daily life in Benin's parastatal sector. The interpretation also attempts to show how imminent democratization, through the creation of a National Conference in early 1990, changed the strategies and the context of workers' protest. It includes a number of exemplary, and quite spectacular, cases of mismanagement and closing of parastatal companies, such as the Société Sucrière de Savè and SONICOG. I would think that the approach is unique so far for both Beninese and West African history.
\end{abstract}

\section{Introduction}

In 1989, despair amongst large parts of Benin's population about the economic situation in the country was deeply entrenched. A spectacular triple bank crash involving the three national banks had destroyed the savings of many. ${ }^{1} \mathrm{~A}$ number of state projects were threatened or suspended; the deal to get a

\section{International Labor and Working-Class History}

No. 98, Fall 2020, pp. 77-98

(C) International Labor and Working-Class History, Inc., 2020. This is an Open Access article, distributed under the terms of the Creative Commons Attribution-NonCommercialNoDerivatives licence (http://creativecommons.org/licenses/by-nc-nd/4.0/), which permits non-commercial re-use, distribution, and reproduction in any medium, provided the original work is unaltered and is properly cited. The written permission of Cambridge University Press must be obtained for commercial re-use or in order to create a derivative work.

doi:10.1017/S0147547919000267 
better financial basis through an International Monetary Fund loan was still in the making; however, some rules pre-negotiated with the IMF had already been imposed. These latter measures led-as I will discuss in more detail - to an even stronger disintegration of the public and parastatal sector, a sector that was already shaken by massive delays in salary payments. Frustration with the authoritarian regime of Mathieu Kérékou and the Parti de la Révolution Populaire du Bénin (PRPB) unity party, which had been increasing over the course of the 1980s, finally reached a peak under those dire conditions it would appear. The intensity of the socioeconomic disaster, which largely surpassed that of other West African societies in the same decade, might explain why Benin underwent a paradigmatic transition from so-called "MarxistLeninist" authoritarian rule to multi-party democracy by means of a national conference. ${ }^{2}$ Scholars working in the 1990s in particular have sometimes regarded the Beninese experience as emblematic of a ("second") democratization process all over sub-Saharan Africa. ${ }^{3}$ As the combination between social cutbacks, beginning IMF interventions, rapid paralysis and subsequent elimination of the parastatal sector, and impressive democratic change is so compelling, Benin is a particularly interesting case for the social historian interested in the transition experience of various groups. Its study helps us to go beyond the existing, limited literature of such experiences, in which the analytical viewpoint of historians is practically missing. Moreover, interpreting the historical experience of certain social groups also sheds light on the rationales of the political process.

This article will focus on a particular group of workers, spokespersons of labourers, engineers, administrators and managers. I will examine here how employees of parastatal companies under the Kérékou regime, as one important group of society affected by the experience of the disastrous decline of a whole sector, made sense of this situation. My interpretation discusses how they tried to communicate about this disaster with the authorities, how they protested and attempted to make claims about social norms and justice, and how they attacked "corruption." Although the cases studied cannot stand for a model of experiences, they nevertheless represent a number of elements of a social history of decline: as well as protests and arguments, and views on the practice of petitioning, the discussion will also highlight individual trajectories that nevertheless exemplify, in my view, representative experiences and a history of daily life in Benin's parastatal sector.

This analysis is possible through a (currently) untapped resource-written complaints and petitions sent in their hundreds to the office of Benin's president, Mathieu Kérékou, with frequently long dossiers of investigation, well hidden in the presidential archives series, a series within the National Archives of Benin. The series is now over 1300 boxes strong, with an inventory that does not normally give clearer information beyond the indication of the beginning and end dates of the files contained in each box - and it is practically unknown. Given the uneven distribution and fragmented nature of sources for the social history of West Africa's post-independence societies, this is an especially impressive archival collection which should really be used much more. Although the 
petitions were sent to the office of an authoritarian ruler, and their authors often conformed to a certain language of enthusiasm for the 'Marxist-Leninist' project of the Kérékou regime, they are frequently very frank in terms of their complaint, which was then discussed in annexes provided by different services and coordinated by the presidential office. Overwhelmingly, despite the occasional pro-regime rhetoric used in the complaints, the disappointment about the dramatic situation is always palpable. In spite of their very critical tone, the petitions do not normally offer clear evidence for cases of corruption and malfunctions, but they help us to understand perceptions and arguments of the members of the group that was most strongly hit by the cutbacks in the public and parastatal sector.

Of course, the 1980s, as a period of historical analysis, are still very recent; however, in other world regions, the opportunities for interpretation notably afforded by the end of the Cold War and access to new, including archival, sources have been more eagerly seized. ${ }^{4}$ For West African experiences of regime change, the signs are somewhat worrying, as the experience of specific social groups would need to be collected as contemporary interview data, or studies would need to rely on pioneering archival research, or both. With regard to the collection of oral testimony, which is perhaps even more urgent, there seems to be little systematic effort. Questions that might later become part of a social history of the 1980s in Benin do obviously appear in Richard Banégas's essential study of the country's transition; but Banégas's work principally tries to understand the political process. In terms of the use of postindependence archives, I would certainly challenge the classic hypothesis of Stephen Ellis that such archives are probably weak sources, and refute the argument frequently published in recent years, and exemplified by Samuel Fury Childs Daly's pessimistic claim that not much can be drawn as empirical data from postcolonial, and especially regional, archives (an observation which may be correct for Nigeria's Biafra region studied by Daly with important results, but which does not hold for many other regions of West Africa). ${ }^{5}$ Benin is one of the cases where much archival research is still waiting for the historians, and that is the case for both the postcolonial series of the National Archives and the documents stored in District and Municipal Archives, which are often only accessible under complicated conditions, but are not at all lost.

The importance of the views and interpretations of workers, departmental managers and labour spokespersons of parastatal companies is interesting in a wider context beyond the Beninese experience. Frederick Cooper has pointed to the-however incomplete-separation between a privileged elite of workers and the majority of West African societies, but has not really followed this process on empirical terms into the postcolonial period. ${ }^{6}$ Sociologists, mainly of the 1960s and 1970s, showed some interest in workers employed in the public and parastatal sector, appearing as a typical phenomenon (in West Africa); they certainly became the greater part of the group of salaried employees in a number of postcolonial states in the 1970s and 1980s. ${ }^{7}$ As David Fashole Luke pointed out in 1984 in the context of his own study on Freetown, Sierra 


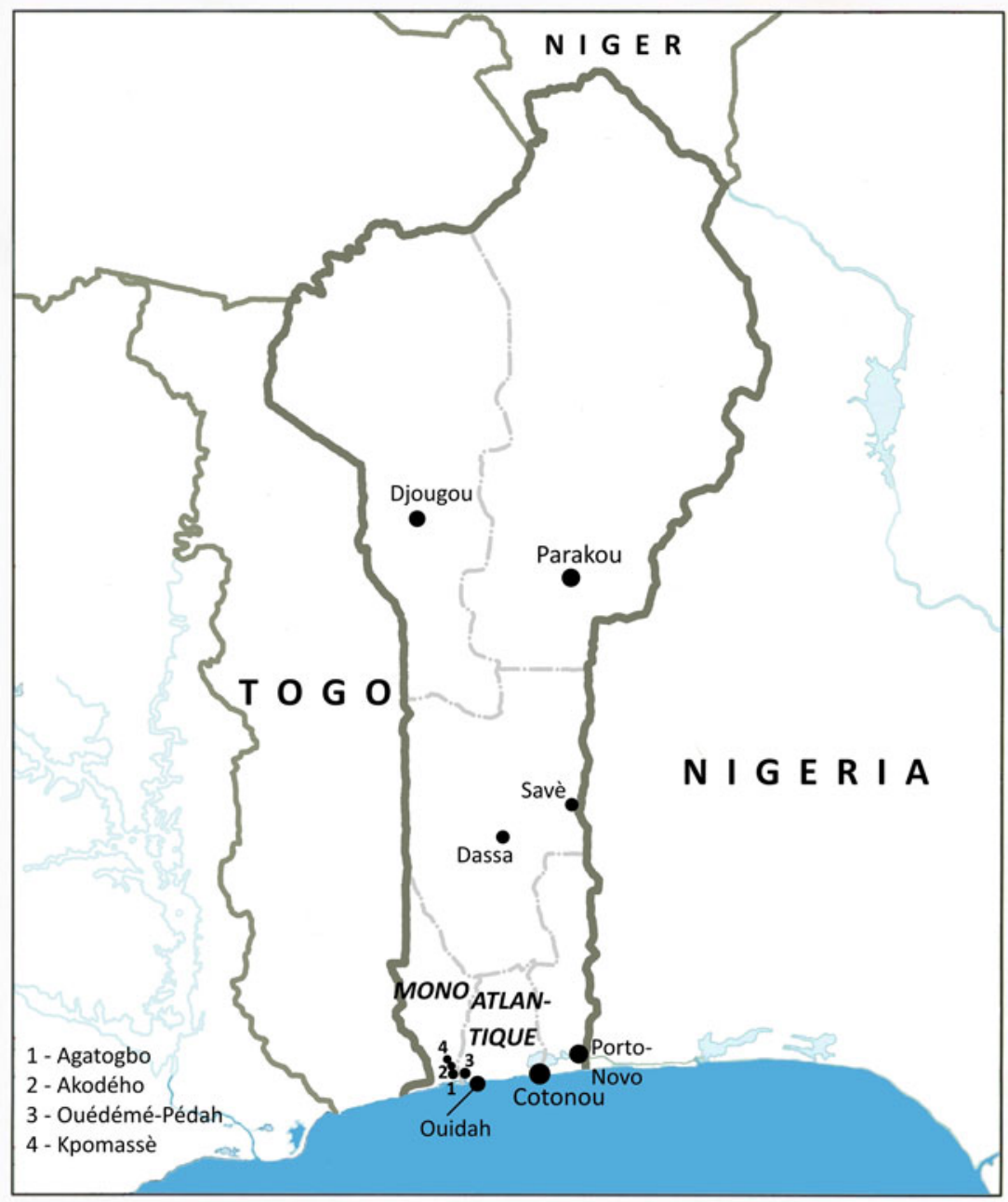

Figure 1. Benin.

Leone, the identifications and positions of such workers were very rarely studied. ${ }^{8}$ This remains a valid comment more than three decades later.

Generally, where sociologists became interested in these workers, they connected to the old theory of this group being a 'labour aristocracy'. ${ }^{9}$ Only in some cases, like that of Margaret Peil's discussion of Ghanaian industry workers as an emergent 'class', were observations on their changing social attitudes included. ${ }^{10}$ However, much of the debate on parastatals has been on questions of political control of these companies, or its absence, and, ultimately, accusations of corruption. ${ }^{11}$ The Zambian experience has been particularly important in that regard. ${ }^{12}$ But the case of Benin now allows us to interpret the trajectory of 
parastatal labourers in the first decades after independence, through their correspondence at a particular moment of crisis.

The petitions and complaints analyzed in this study offer views of experiences at very different levels; two examples will suffice here to give a first snapshot. On November 24, 1989, in correspondence between the National Executive Council and the Ministry of Labour and Social Affairs, we find the petition of Etienne Hountongninougbo, former employee of Construction d'Automobiles du Bénin (the state automobile construction firm) and of the Société Nationale de l'Equipement between 1966 and 1986. When the latter was privatized in 1986, Hountongninougbo lost his job; for three years he failed to find any new employment. In 1989, at the age of 41, he asked for his social security contributions as a lump sum, in the hope of buying land and starting a new life in commercial agriculture. ${ }^{13}$ The ministry denied this request: in the depths of financial crisis, existing funds were said to be insufficient to pay out the resources in question to a single petitioner. ${ }^{14}$

Two and a half months after Hountongninougbo's request, engineeragronomist, François Sanda Orou, an employee at a much higher level of responsibility and salary, but equally desperate, petitioned the office of the presidency with regard to his professional situation. Orou had worked for the CARDER-Mono, the Centre for Rural Action in the Mono Département, and was one of the many who had been "deflated" (déflatés, as the technical term invented for processes of lay-off in Benin and elsewhere, held it) from the state service. ${ }^{15}$ This second case is also significant for experiences with unemployment and the social history of restructuring. Orou had been sent to direct various state firms between 1984 and 1989. During the complex negotiations of the Kérékou regime with the International Monetary Fund, which had led to promises from the Beninese government to dismantle a number of public enterprises but also to a list of public sector officials who were not to be sacked, Orou's name had in 1986 been on this list of officials to be spared. ${ }^{16}$ He had been retained by the CARDER-Mono and held important roles in the further process of closing the declining state enterprise, but had then - ironically - himself been left without work and without salary. Months of protest with various ministerial departments and bureaucratic services changed nothing-only President Kérékou himself seemed able to help. ${ }^{17}$

In the petitions series, employees with secondary education are overrepresented. With the increasing destabilization of the regime, spokesmen of workers' committees and higher-ranking employees are also more and more frequently the authors of petitions. While this perhaps places a limit on the source's value and usefulness, it nevertheless allows for the interpretation of views and opinions of these employees - and, in the case of collective petitions from workers' representatives, they can be considered as interpreting workers' grievances. Although many of the petitions still paid lip service to revolutionary language, they are a window on subaltern processes, and probably more frequently than the nature of the correspondence may suggest at first glance. ${ }^{18}$ This article hopes to exploit these rare views. 
Still confiding (somewhat) in the government? The dynamics of seeking help from the presidency during the decline of the Kérékou state

This first section will focus on public views - including those of the employees of parastatal firms - on the declining Kérékou regime and in particular the Beninese presidency, which involves questions such as corruption, mutual loyalties, and hopes for improvement. The historical perspective on ideas and perceptions on the transition is entirely new. The second wave of democratization in sub-Saharan Africa at the end of the Cold War has so far received considerable interest among scholars who-as political scientists and sometimes as sociologists - accompanied the process. ${ }^{19}$ Recently, this early 1990s experience of challenging authoritarian rule and reinstalling democratic processes has also been subject to more systematic treatment. ${ }^{20}$ Scholars have also attempted-although in less systematic ways - to launch an interdisciplinary discussion of the experience of democratization in connection to the economic performance and problems of postcolonial African states. ${ }^{21}$

Amongst the rare comments of historians on the transition as a whole, only a start has been made by Paul Nugent's important overview identifying a number of essential themes to be analyzed by future generations of scholars. He particularly invites a discussion of associations, religious bodies and a changing media landscape, and their role in what has sometimes indiscriminately been called new "civil society. ${ }^{22}$ For Benin in 1989/90, Richard Banégas, as a political anthropologist, has offered a chronology of the forms and trajectories of antigovernment mobilization. Arguing that in the absence of detailed studies, a social panorama of participants of the movements is difficult to deliver, he nevertheless mentions a number of principal groups challenging the regime: striking staff and students in the education sector throughout much of 1989, but also striking health service employees, and an increasing number of participants in urban demonstrations, which also seems to have triggered rural unrest. ${ }^{23}$ The difference Banégas formulates between that engagement and the protest activity of the 1960s - claiming that in the 1960s protest was triggered by "workers," and not by teachers and public-sector employees - is unconvincing as in the late colonial and early postcolonial West African contexts, members of trade unions often represented a privileged elite in professions that do not correspond to the concept of a "European working-class." 24 As we will see, staff of public and parastatal companies who became unemployed during the economic cataclysm of the 1980s could swell the ranks of the opposition movement, or try to appeal to the Kérékou regime in blaming incompetent ministers and high officialsor practice both strategies at the same time. ${ }^{25}$ But for the rest, Banégas's social panorama is very valuable for the historian, as it shows the heterogeneity of the movement. It also illustrates the use of formulas coming from a religious past, especially that of the oma, which represented in "traditional," religious terms the righteous fury of the victims of misgivings agitating en masse, a concept that was apparently taken from precolonial, southern Beninese (especially Porto-Novo related) religious thought. ${ }^{26}$ These observations link to 
Kadya Tall's affirmations on the importance of vodun principles during the transition, especially, again, in southern Benin. ${ }^{27}$

In spite of the scandals of the Kérékou regime and the massive anger within important groups of the population about the economic decline of the state; in spite, as well, of agitation through pamphlets (initially mainly from activists of the clandestine Parti Communiste du Dahomey that did not correspond to the variant of "Marxism-Leninism" of the regime), many frustrated ex-public sector officials and employees of parastatal firms still had a remainder of trust in something imagined as the principal honesty of the presidency-but not of its ministers and counselors. ${ }^{28}$ The fact that the office of Mathieu Kérékou continued with enquiries into particular cases of "corruption" throughout 1989 and even at a moment, in December of that year, when fundamental regime change and a National Conference had already been announced, did not fail to impress a certain group of petitioners. The accusation against one of Cotonou's principal police commissioners in late 1989 was perhaps less remarkable than what the public could interpret as continuities in office of corrupt ministers. Nevertheless, such cases built the image of a president who was betrayed by a number of his advisors but ultimately tried to remain an honest politician. ${ }^{29}$ This was a very ambiguous idea. Angry petitioners were appalled that the president also remained symbolically committed to the most feared "hardliners" of the regime shortly before the turning point of the National Conference, and that he thus gave in to regime members who hoped for clear signs of defending the deeds of the party and the revolutionary/ Marxist-Leninist state during "this extremely difficult Political, economic and financial crisis." That was one of the many contradictions baffling those petitioners who in principle still maintained a belief in the personage of the president as a benevolent force. ${ }^{30}$ Yet, even so, the idea that the presidency and its office stood out positively in the political process remained important beyond the end of 1989 .

Who was therefore responsible for "corruption" and disaster? That was sometimes complicated to judge for those of the parastatal sector sending in petitions. But with regard to a "moral economy of corruption," to borrow the concept of Pierre-Olivier de Sardan, the presidency retained, for some at least, a reputation as an arbiter, to which scandalous cases could still be submitted. ${ }^{31}$ Once again, the Kérékou regime had certainly further lost a good part of its credit in that regard after the Cissé Affair, when in 1989 it became clear that a longstanding favourite, minister and spiritual advisor of the president, Mohamed Cissé, had expatriated considerable sums of money. But for some time, public distrust and hostility hit the ministers of the regime much more than the president himself.

Some public services that were charged with the organization of labour and the implementation of measures shrinking the public and parastatal sector were also particularly involved in the detection of fraud and "corruption," and they were equally looking to the presidency for moral support. This was certainly the case of the Inspectorate-General of the State. Attacked by the rising 
opposition as an instrument of curtailing welfare for Beninese citizens, lambasted by the "hardliners" of the regime for their occasional enquiries against the protégés of leading ministers and directors, the inspectors formulated a programme of following obligations even through turbulent times. These formulas were immediately subscribed to by the presidency - this might have been pure show, but it underscored the claim of honesty the presidential staff and Kérékou himself still tried to make:

\begin{abstract}
As far as we can go back in the history of the Inspectorate-General of the State, we will always reveal that the fantasist denunciations, calumny, etc ... have often been missiles shot because of enquiries that went too far in various respects, but also by collaborators with ill intentions for their own, unspeakable goals, with the only objective to serve their own needs and destroy our morale. But far from beating us, they are frequently to us what the plough is to the earth: they rip us open to make us more fertile, which means more efficient in our posts. And therefore we seek ways to carry out our task in an even better manner, in order not to fall under the hammer of these ill-intended suspicions, and to relieve us from the challenge of all the evils of which we are unjustly accused. ${ }^{32}$
\end{abstract}

One further turning point in the falling esteem for the president and his office among frustrated employees of the parastatals was probably only in early 1990, thus a bit more than a month before the start of the National Conference. It had to do with a new intensification of restructuring measures demanded by the IMF and international donors. The IMF had, of course, already stepped in to massively support Benin's public budgets, and the downsizing of the public sector in Benin had begun much earlier than was actually agreed between IMF negotiators and the Kérékou government. Occurring in an environment of continuing Marxist-style rhetoric, it had left the workers frustrated and perplexed. ${ }^{33}$ But the sudden sacking of a large number of the employees of parastatal brewery La Béninoise from January 1990 onwards, against all the guarantees given before by the presidency, was too much for many of the more patient of the employees. As a logical consequence of a negotiated IMF package, it destroyed some of the remaining trust in the president's "good work." ${ }^{4}$ An expanding independent press sector from February onwards put these criticisms into enraged attacks. ${ }^{35}$

For the period between early 1989 and early 1990, the picture remains different: the correspondence about the future of work, corruption and mismanagement that appears in communications with the presidency's office is the expression of still conflicting interpretations of the present by the employees of the parastatals. ${ }^{36}$ The office certainly only took a position in a small number of cases. In rare cases, Kérékou's support for the activities and recommendations of his office's advisors even allowed for the overruling of decisions of feared ministers, such as Martin Azonhiho (the Minister of Transport and Equipment), through the establishment of committees which, for example, saved dismissed engineer, Issa Badarou Soulé, the former commercial director of the Port of Cotonou-even if this decision was only expedited on the eve of 
the National Conference. ${ }^{37}$ And, as we will see, even in March and April 1990, such communication between protesting employees and the presidential office still continued, and offers insight into social experiences (the stream of communication tailed off only slowly towards the presidential elections that ended Kérékou's presidency on March 24, 1991).

An attack against the rights of the "good labourer:" the language of injustice, Savè sugar, and other "deflation" experiences in 1989

The second section will debate how protesting workers made their claims and on which perceptions of their role they built their argument; this was especially linked to the rights of the "good labourer." In 1989, the crisis in the parastatal and public company sector sparked increasing written protest in the hope that the presidency might still rectify the unjust situation. Within their protests, former employees of the companies also gave clear statements on their vision of labour and the "good employee," and discussed issues of "corruption" and moments when "good forms" of management were allegedly thrown overboard. Interestingly, while the whole process clearly needs to be read against the background of increasing IMF pressures, the petitioners were not really concerned with the role of such international capitalist institutions, but looked instead to the problems of massive domestic mismanagement and inefficiency in the sector. In these regards, the movement also differed from the parallel Nigerian evolution, for which research has shown the principal importance of the organized labour movement in the debate on democracy and the struggle for democratization. ${ }^{38}$ For Benin, our particular source basis allows for the formulation of social debate on decline and shows the nature of (written) protest, rather than the organization of a particular broader protest and union movement in the parastatal sector at the end of the 1980s.

Under the weight of increasing international pressures towards structural reform, the Beninese administration invented categories that facilitated the release of public company staff. Those were immediately challenged by the employees. Judes Tolli, former employee of the Organisation Commune Bénin-Niger des Chemins de fer et des Transports (OCBN), complained bitterly that he did not fall into any of the categories of undesirable workers whose lay-off had been declared a priority. Tolli-who had had an unstable status before 1984 but had become a regular permanent employee from then onwards - seemed to be the victim of a conspiracy in the opinion of the presidential office. ${ }^{39}$ His complaint illustrates the justification strategy used for the dismissal of personnel within the state firms:

We were present when the Directorate-General of the OCBN publicized Five (5) criteria that would guide the redundancies out of economic reasons, namely:

- The "ethylics" [alcoholics].

- The perpetually sick. 
- The "clochards" [meaning workers who wore rags and were charged with not caring about their attire].

- The idlers.

- The lazy ones. $^{40}$

Tolli agreed with these work ethics, which followed earlier discourses on specialized workers, remodelled into the ideology of the "Marxist-Leninist regime." Further, he expressed his consternation about the "unfair decision" made in his regard. He also insisted that such dismay was widespread in his firm. ${ }^{41}$

Occasionally, personal experiences were couched in the language of regional discrimination. Jean-Baptiste Bana Sani, former director of the Division of Personnel, Material, and the Archives, complained in bitter words about his dismissal from the Conseil National des Chargeurs du Bénin on August 14, 1989. Bana Sani held that practices at the CNCB constituted "without any doubt" a "war against the populations of Northern Benin." 42 The old theme of mistreatment of northern Beninese, in spite of the presidency of "northerner" Mathieu Kérékou, orchestrated by "southern" cliques therefore remained a possible argument. More frequently, however, the principal idea was to contrast the unfair treatment of workers and employees who fully corresponded to the image of the "good labourer" with the greed and incompetence of managing staff that came in from elsewhere-ministries and directorates - and were shuttled out after ruining the enterprise.

Such situations were prevalent in the debates. Amongst a number of sensational closures of state firms and the complicated cases of sacked employees, the Société Sucrière de Savè was a particularly dramatic one. The SSS was a model company, created in 1975 for sugar production in cooperation between the Beninese and the Nigerian state. ${ }^{43}$ As such, it was also subject to the ebb and flow of relations between the Kérékou government and the various Nigerian heads of state. ${ }^{44}$ The dire state of Benin's public budgets in 1983/84 led to a first crisis in the company, which was vividly remembered by the workers because of the hasty departure of the British and Mauritian experts who had carried out some of the specialized work in the concession. Between 1984 and 1989 , the SSS was characterized by the late payment of wages, but the representatives of the workers became especially enraged when in 1988 the firm was bought by the private joint venture AGRIMATEC, formed with Beninese, Nigerian and French capital. Spokesmen H. Gilbert Ahotin, Pascal Aplogan and Janvier Akpo-Dossou as early as July 1989 lamented these "antirevolutionary forms" of activity, which led to a lay-off of more than 1300 workers. ${ }^{45}$ As proof of the accusation they referred to the lack of attention shown by the new owners to existing stock, with bags of treated and untreated sugar and molasses left behind and decomposing in the storerooms. ${ }^{46}$ For the workers, and their representatives, the experience of the company was all the more disturbing as during much of 1988 the National Executive Council of Benin and the Nigerian government had promised to bring in 1 billion Francs CFA 
through loans coming from the West African Development Bank and various private partners, and this had been much publicized amongst the firm's employees. The concession of the SSS to AGRIMATEC had thus come as a surprise decision on September 28, 1988; it had severe effects on the company and staff were infuriated by the lay-offs, but also by what was seen as a general lack of initiative. ${ }^{47}$ Eventually, the security forces dispersed protesting workers. ${ }^{48}$ Nevertheless, the representatives of the workers expressed their conviction that these problems existed unbeknown to the "revolutionary" president and were the results of the actions of a dubious management:

It was scandalous, shameful, humiliating, and even unacceptable that a group depends on two states, and that a firm takes control of a complex of more than 70 billion francs CFA entirely financed by Nigeria, the Lonrho, and Benin. The old leading management was removed without any handover, without a two-party inventory of movable and immovable goods, the agricultural equipment, the consumables, the technical installations ... Until the present day, no contract has ever been signed by the two states and "AGRIMATEC." This is why we ask the two chiefs of state to shed light on the situation of the Société Sucrière de Savè.

\section{$[\ldots]$}

Comrade President, this is the long road, gritted by pitfalls, during which the untiring and committed have sacrificed their wives, children, parents, and themselves for the prosperity of the complex whose survival is a question of conscience for you. Your ambassador, your minister for the industry, your councillors have misled you towards this solution for the Société Sucrière de Savè. This attitude hides many things that you should attempt to know if you are interested in our fate. It is shocking and unthinkable that the chiefs of state accept the violation of the rights of men and work.

$[\ldots]$

Out of personal and egoistic interest, you have been led down a path towards disaster and dishonour. The results are a clear proof. Five months after the installation of "free and private" management, the complex was besmirched by the shedding of blood during this tragic event [of firing on strikers], as a consequence of the lack of conscience of the Administrative Director of the "AGRIMATEC", son of the President Director-General of the Group. ${ }^{49}$

Two months later, the authorities had not given any response to the petitions of the workers, and the town of Savè was full of dismissed personnel-a good part of the 1300 who had once been the principal labour force of SSS had not returned to their villages of origin out of fear of confronting their families, according to their spokesmen. Attacking this situation as "murder," the workers' representatives now threatened the authorities with informing, 
amongst others, the International Labour Organization and the French Embassy in Cotonou. ${ }^{50}$ On January 2, 1990, the same workers' representatives were finally granted an audience with Kérékou - and they renewed the accusations, including a claim to have evidence that 4 million Franc CFA destined to settle pay arrears in October 1988 had disappeared into the pockets of the management. ${ }^{51}$ The protests were finally taken notice of when they reached the level of the president's office: the office's secretary stated his indignation and demanded a serious enquiry into the matter, including the possible theft of public funds, to which there had been no judicial response over a period of more than a year. ${ }^{52}$

The Société de Transit et de Consignation (SOTRACOB) was less symbolic than the SSS, but offers another documented case of protest and of the discussion of social experience of decline through petitions. The SOTRACOB got into financial problems in 1987, with numerous dismissals of staff. Paul Gbénou, Joseph Adah and Joseph Alouké had at that point had careers of between eight and twelve years, first as occasional workers, and then as night watchmen. At the point of liquidation of the firm, they were retained for another two years, but then officially dismissed on May 2, 1989-their unemployment rights were not respected. As the administration of the firm and the Comite pour la Défense de la Révolution (CDR) - the workers' council created, as in all companies, under the Kérékou regime-had not reacted to the complaints of the workers, they managed to mobilize the Inspectorate of Labour, but the management of SOTRACOB never appeared to explain the situation, even when they were officially requested to by the inspectorate. Only through months of pressure did they finally manage to get to see one of the liquidators, Pascal Amoussou. ${ }^{53}$ This did not help to turn the tide, however:

This liquidator did not contest the rights that had thus been calculated by the Comrade Inspector. He even admitted that the complaint was well founded, and proposed to pay a first instalment while the second would only be honoured as soon as the situation at the level of the BCB [Banque Commerciale du Bénin] improved because, as was the case for a good number of companies, their account had also been frozen. Everyone accepted this proposition. But instead of behaving accordingly, the comrades, in the course of last week, changed their minds and are no longer willing to pay.

Comrade President, we would like to draw your friendly attention to the fact that after we were forced (compressed) from the SOTRACOB, we have become jobless people. But we have wives and children to feed and we live in rented houses. Not only we are no longer able to keep our family obligations but our landlords threaten to throw us out. ${ }^{54}$

The office of the presidency reacted-apparently unexpectedly from the point of view of the complainants - on these individual protests, defining the situation of the workers as entirely unacceptable and their social conditions as 
desperate. ${ }^{55}$ A week before the start of the National Conference, Kérékou met personally with the petitioners, Amoussou and representatives of the firm's management: the insistence of the presidential office's members led in this case to the payment of a certain sum, although it remains unclear how much was actually handed out to the ex-workers in distress in a context of massive turbulence. ${ }^{56}$ The liquidator, Pascal Amoussou, was similarly accused by former staff of the hotels in Cotonou who remained without their promised payment arrears, but these cases of liquidation only became the subject of controls and enquiries with the deteriorating situation at the end of $1989 .^{57}$

Therefore, in the case of the SSS experience (as a symbolic example where even prestigious transnational cooperation had failed) but also a striking number of lesser-known cases, sacked employees, and some colleagues who still held their positions but had been moved to outlying branches of firms, managed to mobilize a certain language of injustice. In their petitions to ministers, and especially to the presidency, they referred to the need for protection, and increasingly attacked particular figures of the regime, and, more broadly, some formerly feared institutions, such as, notably, the gendarmerie. Although the political changes within Benin would later become more apparent, this represented a courageous approach with important elements of the authoritarian state - a state, however, which already showed more fissures than had been the case in the late 1970 s and the early 1980 s.

To "be done with corruption:" the SONICOG affair and the accusations within public and parastatal companies during and after the National Conference

Changes in workers' perceptions and strategies during the phase of more accelerated political transition, during the National Conference, are the focus of my article's third section. The National Conference between February 19 and 28, 1990 fundamentally changed the political situation in Benin. As a consequence of the conference, power within the state was mainly taken away from President Kérékou, who now had to accommodate a High Council of the Republic and to cohabit with a newly installed, hostile prime minister, Nicéphore Soglo; until the 1991 presidential elections (which he lost against Soglo), Kérékou's influence was severely curtailed. This definitely modified the dynamics of communication about economic decline and the failures of the regime: the increase in independent medias, the officialization of new trade unions, and the return of exiles all changed the possibilities for criticism with regard to the public sector and parastatal firms. ${ }^{58}$ Even so, the whole process came totally unexpectedly for the elite of the regime. Even on January 3, 1990, with the National Conference in sight, the Secretary-General of the National Executive Council, Godfried Johnson, congratulated himself that public sector personnel would finally be willing to end the long strikes and go back to work, given the clear and considerable effort shown by the government. The blame was internally put "on some degenerate elements full of laziness and friends of disorder [who] spread threats of terrorism amongst the 
great mass of the workers," and the president himself was thus called upon to take the initiative with a huge information campaign. ${ }^{59}$

Much has been written already on the National Conference and the different pressure groups that made it possible to dethrone Kérékou: a comparison with the parallel, Togolese development-with a fundamentally different outcome - is also part of this debate. ${ }^{60}$ However, interpretations that we have so far are mainly the work of political scientists, and the transition process should certainly be revisited by historians; the presidential series from the Archives Nationales du Bénin will in the future also provide important source material for that, which could be combined with testimony from participants. In this article, I pursue a more modest objective, trying to see how employees of parastatal firms reacted to this massive change, through a case comparable to those of the SSS and other public firms, but in which petitions became a principal vehicle only by the end of the National Conference. This will aid with the understanding of how both the experience of workers and the form of petitioning and criticism changed after February 1990.

Unsurprisingly, the accusations became more direct and included major verbal attacks on certain regime members - and not only in correspondence with the opposition or the new prime minister, but also in petitions to the president. These attacks need to be interpreted with some caution, especially as decline in Benin was now more than ever blamed on specific individuals and less still on the president, who remained in an ambiguous role as concerns the view of public and parastatal company workers (practically all of which had entered their functions under the regime). In some cases, the individuals targeted by workers' rage were later on rehabilitated, and became ministers again and even presidential candidates; in early 1990, they thus may well have been scapegoats for the expression of wider discontent. ${ }^{61}$ I therefore need to insist here that the petitions do not serve as evidence of historical fact and proof of accusations, but they are useful for reconstructing the arguments (and wider perceptions) during the mobilization of employees in the parastatal sector. From the attacks against the management of such firms, we currently only know the petitioners' view (which is, of course, insufficient to come to any clearer verdict on responsibilities) - and the historian could hardly replace legal opinion and, especially in such recent cases, would certainly not want to. ${ }^{62}$ But it is important to understand social experiences contained in the petitions, and to deconstruct the debates in a rapidly changing context.

After February 1990, the intriguing mix of revolutionary language and accusations of abuse and theft continues to help us in understanding workers' perspectives and the language of attacks. One of the most dramatic cases was that of the Société Nationale pour l'Industrie des Corps Gras (SONICOG), an essential parastatal firm in the palm oil products sector, where the directorgeneral, a former minister for planning and statistics between 1984 and 1987, became a particular object of attacks and a kind of symbolic enemy of workers' interests. ${ }^{63}$ Worker delegates accused the director-general of 
continuing with bad practices within this company, emulating alleged former behaviour as minister and as director-general of the Société des Ciments du Bénin (SCB). While closing the oil mills in Cotonou, the SONICOG imported oil from Togo; at the same time, the management of the firm was charged with the organization of luxurious company parties. ${ }^{64}$ In the name of the "democratic renewal" - "the framework of normalizing political life in view of installing democracy, liberty, and transparency in the management of the Affairs of the Nation" 65 - the worker delegates described the director-general as an old protégé of Vilon Ghézo-regarded by many as an emblematic figure, i.e. as the most fearsome hardliner of the regime-and as a particularly corrupt individual. ${ }^{66}$

The more general mood was dire. The workers of the company lived in permanent fear of upcoming social disaster, as, according to the worker delegates, the

SONICOG traverses a critical situation, but a situation that is at every turn obscured by the team in charge, this being then a situation that includes the danger of dragging the firm towards a financial abyss, if the responsible individuals do not refrain from confusing their own, private budget with that of the company. In order to avoid facing the same fate as the agents of the SCB; BBD [Banque Béninoise du Développement]; AGB [Alimentation Générale du Bénin]; etc... the workers of the SONICOG have at different times sounded the alarm bell, handing in a motion and a declaration. This has not concerned and prompted any reflection amongst the responsible team of the SONICOG ... [which has] rather decided to punish the workers and to continue the pillage of the SONICOG ... ${ }^{67}$

The accusation against the director-general as source of all evil was also easy to reconcile with the less straightforward results of the National Conference, as for many the fate of President Kérékou himself was impossible to predict. $^{68}$ The comments illustrate the feeling of massive injustice for which company management was held responsible, the nascent movements of the political opposition themselves taking a clear position by reminding the presidency of the need to reinstall dismissed workers and pay the outstanding arrears (something that would never fully be done). ${ }^{69}$ But the workers' comments were still sent to Kérékou and his presidential office! By 1989, desperate workers waiting weeks for their delayed wages took containers of oil to sell privately, and were severely punished. This was presented as a considerable injustice, as members of the management were said to use the firm's money for themselves. Such alleged acts were discussed as unacceptable, and the petitioners attacked the so-called "dictatorship" of the director-general,

which is such that he does not hesitate to blame, with a negative comment in the personnel file, those central directors and heads of service who are seen as 
recalcitrant and also to inflict arbitrary sanctions upon the workers, sanctions that continue up to two years [...] of suspension for the theft of 10 litres of oil while at the same time he turns a blind eye to the squandering of his cousin, Sieur Badarou, Director of Huilerie Mixte de Cotonou (HMC), who currently empties the oil stocks of BENOR, FATIMA and King's he seized on the markets. ${ }^{70}$

In the weeks after the initial attack, the delegates delivered what they regarded as proof of manipulated figures and statistics. ${ }^{71}$ At the same time, they held that the management of their firm tried to remove critics, to send them to remote places and avoid their accusations after the regime changes that the National Conference was likely to create. Again, the protesting employees held that the presidency did not have anything to do with these problems - but that the management was the problem:

They thought it best to choose the days after February 19, 1990, to carry out their operation so that the state authorities, intent on the National Conference, would not have the time to deal with the complaints.

Thus on February 20, 1990, at 1040 hours they distributed to the persons concerned the decision $\mathrm{N}^{\circ} 005 / 90 / \mathrm{SONICOG} / \mathrm{DG}$ announcing the distribution of agents and asking the agents in question to take up their new posts on Friday, February 23, 1990 at the latest without providing them with any resources.

The majority of the persons concerned are people:

- Who have been demanding a General Assembly (AG)

- Who have dared to speak on Thursday, February 1, 1990

- Who are hostile to the performance of the current management

- Who hold information on the disastrous management by the Director-General.

$[\ldots]$

Those of the Administrative Directorate who are redistributed have the dossier on the distribution of presents in their possession so they have been sent into the remote north to silence them.

Today we are without any work because we cannot do anything in the new posts without offices and without buildings. At Parakou we stay under the trees watching the passers-by, and it is the same at Djougou, Dassa and in the other units. We are put into quarantine like lepers or pests because we are suspected to be rebels.$^{72}$

In 1989, the idea of poor performance of the company management was not necessarily shared by everyone, and an NGO that had newly started its activities in Benin praised the SONICOG for its vigilance in questions of food distribution. ${ }^{73}$ But by April 1990, the wave of protests against the director of the SONICOG 
became so massive that Kérékou kept his distance from the behaviour of the company's management, and the office of the presidency proposed a rigid enquiry. ${ }^{74}$ It seems that the protest within the firm and many others died down during the more general drive towards political mobilization, the constitutional referendum and the 1991 elections - but this would need to be analyzed in much more detail for the 1990s. For a social history of the transition in the parastatal sector, and the changing modalities of mobilization, the cases discussed are certainly important.

\section{Conclusion}

Petitioners, whether they are workers or higher-level employees of parastatal firms in Benin, are not neutral observers. They have a clear objective, which is to get the head of state and his office to overrule decisions made by the management of public or parastatal firms; to intervene in cases that had been left unresolved by ministries and directorates. Within such petitions, conditions need to be shown to be particularly desperate, and certain members of the companies' managements at least presented as particular villains of the scenario.

However, in spite of these biases, the interpretation of the $1989 / 90$ petitions gives us important insight into social experiences within the parastatal and public sector at the end of the Kérékou regime, and the norms and attitudes linked to employment in a parastatal company. I would even hold that such petitions are a particularly outstanding source, if interpreted with caution. First of all, they show the experience of 'being laid off' as a complex process: workers were formally dismissed but retained with a view to being quickly reincorporated, trusting in the willingness of the company to improve the situation and accumulating unpaid arrears for two or three years. In the case of SSS personnel in the smaller town of Savè, we also find the phenomenon of workers refusing to believe that they really had to return to their regions of origin. Many survived for months waiting for better prospects; but in Cotonou in particular, where renting a room was more expensive, such workers quickly got into problems with their landlords.

Secondly, workers at all levels of the public and parastatal companies' hierarchies became very vocal in demanding their rights. They referred to the images crafted by the Kérékou regime (and which partly seem to follow earlier, colonial discussions of the "good African worker") that had defined the useless and dispensable part of the staff - and protested that they were far from falling into those categories. In asking for justice, a remarkable number of these workers had no problems in going to the highest level of the regime.

Thirdly, aside from the accusations of actual corruption - which are difficult to discuss for the historian - it can be said that company management clearly played for time. Public officials who were sent into firms to liquidate them also lived with the constant fear that, with the job finally gone, they could ultimately find themselves on a list of posts to be eliminated. This motivated a more 
cautious approach, keeping workers in the orbit of the firm even when the process of dismantling the structure seemed inevitable. Liquidators used the same strategy to keep enraged workers at bay.

But trust in the Kérékou presidency continued up to a point. Perhaps this is a further explanation for Mathieu Kérékou winning back the presidency in 1996, being a successful "chameleon," as Banégas put it. In any case, the office of the presidency showed a certain performance in a-partly staged-battle against corruption and mismanagement in the public and parastatal sector. The documentation we currently have shows that at certain moments, members of the presidential office were outraged by management failures and the long-lasting hard conditions for workers in that sector, and the president could become very insistent in some cases. While the National Conference made of Kérékou a toothless tiger, petitioners still came to him, and the prestige of the presidency with angry workers was not entirely lost. However, from February 1990, the same workers played even more frequently the card of accusing the old guard of the regime of "corruption," elaborating clear narratives and even clearer villains, and combining it with formulas of "democracy" and "renewal." A more active presidency now only had limited means to respond to those demandsbut it continued to show its presence. Could that strategy have helped to restore part of Kérékou's prestige, not in view of the 1991 electoral defeat, but of the 1996 resurrection? It is plausible that amongst the group of former employees of parastatals some held that the regime had failed, but that, perhaps, the president had just been a misinformed leader, betrayed by his entourage, who could receive one more chance. Together with other strategic moves and with the regional concentration of the vote (the north-south bias in the second round), this might indeed be one further element in explaining Kérékou's remarkable comeback of 1996.

\section{ACKNOWLEDGEMENTS}

The research for this article found generous support from the Swiss National Science Foundation (SNSF) through SNSF Research Professors Grant no. 157443.

\section{NOTES}

1. Philippe Noudjenoume, La démocratie au Bénin: 1988-1993: bilan et perspectives (Paris, 1999); Richard Banégas, La démocratie à pas de caméléon: Transition et imaginaires politiques au Bénin (Paris, 2003), 82.

2. Rachel M. Gisselquist, "Democratic Transition and Democratic Survival in Benin," Democratization 15 (2008): 789-814, 791-94.

3. Bruce A. Magnusson, "Democratization and Domestic Insecurity: Navigating the Transition in Benin," Comparative Politics 33 (2001): 211-30.

4. See the early interpretations of Eastern European history exemplified in Silvio Pons and Federico Romero, eds., Reinterpreting the End of the Cold War: Issues, interpretations, periodizations (Oxford/New York, 2005); the early extensive use of archival sources (together with oral history in other studies) is demonstrated in Charles S. Maier, Dissolution: The Crisis of Communism and the End of East Germany (Princeton, 1997). 
5. Stephen Ellis, "Writing Histories of Contemporary Africa," Journal of African History 43 (2002), 1-26; Samuel Fury Childs Daly, "Archival Research in Africa," African Affairs 116 (2017): 311-20.

6. Frederick Cooper, Decolonization and African society: the labor question in French and British Africa (Cambridge/New York, 1996).

7. David L. Lindauer, Oey Astra Meesook and Parita Suebsaeng, "Government Wage Policy in Africa: Some Findings and Policy Issues," World Bank Research Observer 3 (1988), 1-25; for the start of a historical overview, in a state where the public only eclipsed the private sector as employer for workers in the 1970s-Senegal-Babacar Fall, Le travail au Sénégal au XXe siècle (Paris/Berlin, 2011).

8. David Fashole Luke, Labour and Parastatal Politics in Sierra Leone: A Study of African Working Class Ambivalence (Washington DC, 1984).

9. On this large (and rather unfertile) debate, see Keith Hinchliffe, "Labour Aristocracy-a Northern Nigerian Case Study," Journal of Modern African Studies 12 (1974), 57-67; Richard Jeffries, "The Labour Aristocracy? Ghana Case Study," Review of African Political Economy 2 (1975), 59-70; Peter Waterman, "The 'Labour Aristocracy' in Africa: Introduction to a Debate," Development and Change 6 (1975), 57-74; Jane L. Parpart, "The 'Labor Aristocracy' Debate in Africa: The Copperbelt Case, 1924-1967," African Economic History 13 (1984): 171-91.

10. Margaret Peil, The Ghanaian Factory Worker: Industrial Man in Africa (Cambridge, 1972); Richard Jeffries, Class, Power and Ideology in Ghana: the Railwaymen of Sekondi (Cambridge, 1978).

11. For an overview of the Senegalese experience, see Marc Bellitto, Une histoire du Sénégal et de ses entreprises publiques (Paris, 2001).

12. Ben Turok, "Control in the Parastatal Sector of Zambia," Journal of Modern African Studies 19 (1981): 421-45.

13. Godfried Johnson, Secretary-General of the National Executive Council, to Minister of Labour and Social Affairs, Au sujet de la demande d'intervention formulée par le Camarade Etienne Hountongninougbo S/C Léon Tchoetchou-BP 386 Cotonou. (n ${ }^{\circ} 4102 /$ SGCEB/C), November 24, 1989, box 923, Archives Nationales du Bénin, Porto-Novo, Benin (henceforth ANB), Archives Présidentielles (henceforth PR).

14. Paul Irénée Zinsou, Minister of Labour and Social Affairs, to Mathieu Kérékou, $A / S$ de la demande de remboursement des cotisations personnelles formulée par le Cde Etienne Hountongninougbo.- (nº 0039/IM.T.A.S./D.G.M.), February 8, 1990, box 923, ANB, PR.

15. Note à l'Attention de Monsieur le Président de la République-Demande d'intervention. (without number), January 22, 1990, ANB, PR.

16. Alice Sindzingre, "Institutions, incertitude et ajustement structurel: l'exemple du Bénin," Zeitschrift für Afrikastudien 23/24 (1995): 111-55.

17. François Orou Sanda, Engineer-Agronomist, Director of Conditioning Service of Agricultural Products of CARDER-Mono, to Mathieu Kérékou, demande de régularisation de ma situation administrative (without number), January 8, 1990, box 987, ANB, PR.

18. Although I do not seek a theoretical debate of "subaltern" effects here, my thoughts follow the important discussion by Christopher J. Lee, "Subaltern Studies and African Studies," History Compass 3 (2005): 1-3; and the (already classic) Frederick Cooper, "Conflict and connection: rethinking colonial African history," American Historical Review 99 (1994): 1516-45.

19. Michael Bratton and Nicolas van de Walle, Democratic Experiments in Africa: Regime Transitions in Comparative Perspective (Cambridge, 1997).

20. See the systematic, handbook-style debate in Nic Cheeseman, Democracy in Africa: Successes, Failures, and the Struggle for Political Reform (New York, 2015), 86-113.

21. Nicolas van de Walle, African Economies and the Politics of Permanent Crisis (Cambridge, 2001).

22. Paul Nugent, Africa since Independence: A Comparative History (second edition, London/New York, 2012 [2004]), 378-402.

23. Banégas, Démocratie, 116 for the limits of social analysis, and 93-123 for the various groups of protesters and their goals.

24. On strikers in Dahomey/Benin in the turbulent 1960s, see Emmanuel Terray, "Les révolutions congolaise et dahoméenne de 1963: essai d'interprétation," Revue Française de Science Politique 14 (1964): 917-42; and Alexander Keese, "First lessons in neo-colonialism: the personalisation of relations between African politicians and French officials in 
sub-Saharan Africa, 1956-1966," Journal of Imperial and Commonwealth History 35 (2007): 593-613; for a possible difference between the 1963 and the 1989/90 regime changes, see Banégas, Démocratie, 116; on the concept of work under French late colonialism, see Frederick Cooper, Decolonization and African society: the labor question in French and British Africa (Cambridge/New York, 1996).

25. Banégas, Démocratie, 77.

26. Banégas, Démocratie, 128-33.

27. Emmanuelle Kadya Tall, "De la démocratie et des cultes voduns au Bénin," Cahiers d'Etudes Africaines 35 (1995): 195-208.

28. These individuals were certainly in their large majority not PRPB hardliners following the definition of Banégas, Démocratie, 88 .

29. Captain Sorogui W. Boro, Aide-de-Camp of the President of the Republic, to Secretary-General of National Executive Council. (no. 066/2-//PR/ADC.), January 26, 1990, box 987, ANB, PR.

30. Of high symbolic importance in that regard was the debate in General Barthélémy Ohouens to Mathieu Kérékou, Décoration à décerner à Monsieur Romain Vilon Guézo (no. 10-C/PR/G.M.O.N.B./SA/ST/BON/SC.), January 30, 1990, box 987, ANB, PR, p. 1; Godfried Johnson, Secretary-General of National Executive Council, to Grand Chancellor of Ordre National du Bénin, Au sujet de la décoration à décerner à Monsieur Romain Vilon-Guézo Président du Comité Permanent de l'Assemblée Nationale Révolutionnaire admis à la retraite le $1^{\text {er }}$ Octobre 1989 (nº 0200/SGCEN/C), January 25, 1990, box 987, ANB, PR.

31. Pierre Olivier de Sardan, "A Moral Economy of Corruption in Africa?, Journal of Modern African Studies 37 (1999): 25-52.

32. Octave Jean-Marie Roko, Inspector of Labour, to Mathieu Kérékou, Au sujet des travaux de la Commission chargée de vérifier les malversations qui seraient commises par le Camarade Georges Cohovi Gandonou, précédemment Chef du Service Routes de Dessertes Rurales au Ministère de l'Equipement et des Transports. (no. 414-C), October 12, 1989, box 987, ANB, PR.

33. Abdou Ramanou Ali, "Les Rapports de l'Organisation Internationale du Travail avec le Bénin en matière de protection des travailleurs" (Mémoire, Administration du Travail, Cotonou, Ecole Nationale d'Administration, 1988).

34. Note à l'Attention de Monsieur le Président de la République: Au sujet de la mise en gérance libre des dépôts de «La Béninoise ». (no. SAB-JS/IA.), January 22, 1990, box 987, ANB, PR, p. 1.

35. Marie-Soleil Frère, Presse et démocratie en Afrique francophone: Les mots et les maux de la transition au Bénin et au Niger (Paris, 2000), 59-118; W. Joseph Campbell, The Emergent Independent Press in Benin and Côte d'Ivoire: From Voice of the State to Advocate of Democracy (Westport, CT/London, 1998), 29-54.

36. Kérékou was still held by many individual petitioners to be an "ardent defender of the oppressed and exploited classes"-for what this rhetoric was worth - and some cases of individual arrest and suspension were indeed stopped by the presidency without any indication for clientelist networks, see, for example, K. Georges Eké of Bélipeche Company to Mathieu Kérékou (without number), September 20, 1989, box 987, ANB, PR.

37. Captain Pascal Tawes, Police Officer Jean N'Kiabola M'Po, Police Commissioner Nicolas Kpadjouda, Police Inspector Orou Benoît Sanni, as Commission of Enquiry instituted by Decree no. 89-401 of November 15, 1989, to Mathieu Kérékou, Reprise de service de Monsieur Badarou Soulé Issa.- (no. 017/BGP/CSE.-), February 12, 1990, box 988, ANB, PR, p. 1.

38. Julius O. Ihonvbere, "Organized Labor and the Struggle for Democracy in Nigeria," African Studies Review 40 (1997): 77-110.

39. Note à l'Attention de Monsieur le Président de la République: Demande d'intervention de Monsieur Tolli Judes au sujet d'un licenciement abusif. (without number), April 2, 1990, box 987, ANB, PR, p. 1.

40. Judes Tolli to Mathieu Kérékou, Licenciement abusif. (without number), November 22, 1989, box 987, ANB, PR, p. 2.

41. Ibid., pp. 2-3.

42. J. Baptiste Bana Sani to Mathieu Kérékou, Régionalisme au CNCB (without number), November 15, 1989, box 987, ANB, PR, p. 2.

43. On the second major joint project, the Société des ciments d'Onigbolo at Pobè, see John O. Igué, Le territoire et l'Etat en Afrique: Les dimensions spatiales du développement 
(Paris, 1995), 172-4; for the context of Nigerian-Beninese cooperation, see Michel Houndjahoué "Notes sur les relations internationales du Bénin socialiste: 1972-1986," Etudes internationales 18 (1987): 371-88.

44. Emeka Nwokedi, "Nigeria-Benin relations: the joy and anguish of bilateralism," Genève-Afrique 29 (1991): 33-52.

45. H. Gilbert Ahotin, Pascal Aplogan, and Janvier Akpo-Dossou, Workers of the Beninese-Nigerian company, Société Sucrière de Savè, to Minister of Industry and Energy (without number), November 15, 1989, box 987, ANB, PR, p. 2.

46. H. Gilbert Ahotin, Pascal Aplogan, and Janvier Akpo-Dossou to Mathieu Kérékou (without number), July 27, 1989, box 987, ANB, PR.

47. H. Gilbert Ahotin, Pascal Aplogan, and Janvier Akpo-Dossou to Mathieu Kérékou, doléances. - (without number), September 27, 1989, box 987, ANB, PR, pp. 1-5.

48. H. Gilbert Ahotin, Pascal Aplogan, and Janvier Akpo-Dossou to Ministry of Industry and Energy (without number), November 15, 1989, box 987, ANB, PR, p. 1.

49. H. Gilbert Ahotin, Pascal Aplogan, and Janvier Akpo-Dossou to Mathieu Kérékou, doléances.- (without number), September 27, 1989, box 987, ANB, PR, pp. 5-6. Lonrho, the London and Rhodesian Mining Company, was one of the original investors of the SSS project, see Antoine Yves Tohozin, "Les expériences de cooperation économique transfrontalière: bilan et perspectives," in John O. Igué, ed., Les Etats-nations face à l'intégration régionale en Afrique de l'Ouest: Les cas du Bénin (Paris, 2006), 167-97, 180-4.

50. H. Gilbert Ahotin, Pascal Aplogan, and Janvier Akpo-Dossou, to Minister of Industry and Energy (without number), 15 November 1989, box 987, ANB, PR.

51. H. Gilbert Ahotin, Pascal Aplogan, Janvier Akpo-Dossou, Fiche à l'attention $d u$ Camarade Président de la République Populaire du Bénin: Au sujet des revendications des travailleurs compères de la société sucrière de Savè. (without number), January 2, 1990, box 987, ANB, PR.

52. Note à l'Attention de Monsieur le Président de la République: Revendications des travailleurs déflatés de l'ex-Société Sucrière de Savè. (without number), January 12, 1990, box 987, ANB, PR, p. 1.

53. Paul Gbénou, Joseph Adah, Joseph Alouké to Mathieu Kérékou, Plainte.- (without number), September 9, 1989, box 987, ANB, PR, pp. 1-2.

54. Paul Gbénou ..., Plainte, box 987, ANB, PR, p. 2.

55. Technical advisor on administrative affairs, Note à l'Attention de Monsieur le Président de la République: Demande d'intervention de Mrs Adah Joseph et consorts, Agents de l'ex-SOTRACOB. (without number), February 8, 1990, box 987, ANB, PR.

56. Godfried Johnson, Secretary-General of the National Executive Council, to Minister of Justice, charged with the inspection of Public and Semi-Public Companies, Au sujet de la liquidation des droits de licenciement des Agents de l'Ex-SOTRACOB. (no. 0405/SGCEN/C), February 14, 1990, box 987, ANB, PR.

57. Célestin Kpossou, former staff of Hôtel de la Plage, Cotonou, to Mathieu Kérékou (without number), April 24, 1989, box 987(2), ANB, PR.

58. Noudjenoume, Démocratie.

59. Godfried Johnson to Minister of Labour and Social Affairs, Minister of Mid-Level and Higher Education, Minister of Primary and Basic Education, and Minister delegated to the President of the Republic, charged with the Interior, Public Security and Territorial Administration, Au sujet de la reprise du travail par les Agents Permanents de l'Etat ( $\mathrm{n}^{\circ}$ 0003/ SGCEN/C), January 3, 1990, box 987(2), ANB, PR, p. 1.

60. John R. Heilbrunn, "Social Origins of National Conferences in Togo and Benin," Journal of Modern African Studies 31 (1993), 277-99.

61. This is obvious from discussions of the later, successful careers; see, for example, Maturin C. Houngnikpo and Samuel to Decalo, Historical Dictionary of Benin (fourth edition, Lanham/Toronto/Plymouth, 2013), 313-4. They have also not appeared in the context of Richard Banégas's recent, and interesting, discussions of authoritarian tendencies in Benin after 2006, see Richard Banégas, "L'autoritarisme à pas de caméléon? Les dérives de la révolution passive démocratique au Bénin," Afrique Contemporaine 249 (2014): 99-118.

62. See the insightful reflections from a neighbouring field - the history of accounting - in Christopher J. Napier, "The Historian as Auditor: Facts, Judgments and Evidence," Accounting Historians Journal 29 (2002): 131-55.

63. On the earlier context of the firm, see also Victoire Sodoga, "La Gestion des archives dans les sociétés et offices d'Etat en R.P.B.: cas de la SONICOG et de l'OBSS" (Mémoire: 
Sciences et Techniques de l'Information Documentaire: Archivistique, Abomey-Calavi, Ecole Nationale d'Administration, 1986).

64. Jean Kowhagni, Benoît Hinvi, Hervé Atadi, Anicet Edown, Raphaël Allognon, H. Amadji, Philippe Téhou, Sylvestre Chabossou, Epiphane A., Justin Tchédé, Marcellin Lalèyè, P. Codohne, Workers of SONICOG, Rapport Général sur la Gestion Désastreuse de [...] Directeur Général de la SONICOG (without number), March 12, 1990 (henceforth Rapport Gestion SONICOG), box 987, ANB, PR.

65. Rapport Gestion SONICOG, box 987, ANB, PR, p. 1.

66. Rapport Gestion SONICOG, box 987, ANB, PR, p. 4.

67. Rapport Gestion SONICOG, box 987, ANB, PR, p. 1.

68. This is so in spite of what Kathryn Nwajiaku termed the "weak bargaining position" of Kérékou at the start of the National Conference, as the dramatic outcome of the conference was impossible to predict. See Kathryn Nwajiaku, "The National Conferences in Benin and Togo Revisited," Journal of Modern African Studies 32 (3): 429-47.

69. As an example of this correspondence, see Note à l'Attention de Monsieur le Président de la République: Demande d'intervention de l'Association des Démocrates Libéraux (without number), April 9, 1990, box 987, ANB, PR, p. 1.

70. Rapport Gestion SONICOG, box 987, ANB, PR, p. 1.

71. Allognon to Mathieu Kérékou (without number), March 29, 1990, box 987, ANB, PR, p. 4.

72. Ibid., p. 2-3.

73. Administrative Council of Bénin-Solidarité-Vie (at Paris) to Mathieu Kérékou, Lettre ouverte (without number), December 11, 1989, box 987, ANB, PR.

74. Note à l'Attention de Monsieur le Président de la République: A/S Demande d'intervention de Monsieur Allognon Raphaël-Audience Populaire du 29 Mars 1990 (without number), April 3, 1990, box 987, ANB, PR, p. 2. 